\title{
Gender Difference in the Coronary Risk Factors Amongst the Patients with Acute Coronary Events in Nepal
}

\author{
Bharat Rawat, Abhinav Valdya, Jessen Gurung, Subhash Acharaya, \\ Pravesh Basnet, H.S. Sodhi, Dambar Bahadur Karki, Sunil Chandra Jha \\ Norvic - Escorta international Hospital, Kathmandu, Nepal
}

\begin{abstract}
:
Background: Acute Coronary Event (ACE) is the commonest cause of admission in Coronary Care Unit (CCU) in Nepal. With growing epidemic of coronary artery disease in Asian countries, there is an urgent need to assess the locally prevalent coronary risk factors. There seems to be a significant difference in the risk factors amongst male and female population. Methods: A prospective analysis was done in 404 consecutive patients admitted with an acute coronary event in CCU in the Norvic Escorts Health Care And Research Centre, Kathmandu from January 1999 to July 2002 .The data was analyzed and various risk factors were stratified. Results: Out of 404 patients of ACE, 251 (62\%) patients were males and $153(38 \%)$ patients were females. The commonest risk factors amongst male patients were smoking in 160 (64\%), hypertension in 148 (59\%) and dyslipidemia in $133(53 \%)$, followed by diabetes in $80(32 \%)$ and a positive family history in $65(26 \%)$ patients. As against this, female patients had commonest risk factors as hypertension in $71(47 \%)$, diabetes in 71 (47\%) and smoking in 64 (42\%), followed by a positive family history in 47 (31\%), and dyslipidemia in $23(15 \%)$ patients. Conclusions: Smoking is the most common risk factor followed by Hypertension and Dyslipidemia in male patients with ACE, but most female patients with ACE have Hypertension as the most common coronary risk factor followed by diabetes mellitus. This may be partly due to the difference of socio-economic status of two genders in Nepal. An aggressive preventive approach is mandatory to decrease the expensive burden of coronary artery disease in this poor Himalayan country.
\end{abstract}




\section{Background:}

In the Framingham Heart Study, 26-year follow-up of men and women aged 35 to 84 years indicated that CAD morbidity was twice as high in men as in women, and 60 per cent of coronary events occurred in men, ${ }^{1}$ The onset of symptomatic CAD is typically about 10 years earlier in men, but CAD incidence in women increases rapidly at menopause. Women have the same modifiable risk factors as men, ${ }^{2}$ although diabetes appears to confer greater risk in women than in men, ${ }^{3}$ as may low HDL cholesterol and elevated plasma triglyceride. ${ }^{4}$

Acute Coronary Event (ACE) is the commonest cause of admission in Coronary Care Unit (CCU) in Nepal. With growing epidemic of coronary artery disease in Asian countries, there is an urgent need to assess the locally prevalent coronary risk factors. There seems to be a significant difference in the risk factors amongst male and female population. Not much data is available to assess if coronary risk factors were different in male versus female South Asian population.

\section{Method and observations:}

A prospective analysis was done in 404 consecutive patients admitted with an acute coronary event in CCU in the Norvic Escorts International hospital, Kathmandu from January 1999 to July 2002 .The data was analyzed and various risk factors were stratified.

Out of 404 patients of ACE, 251 (62\%) patients were males and 153 (38\%) patients were females. The commonest risk factors amongst male patients were smoking in 160(64\%), hypertension in 148 (59\%) and dyslipidemia in 133 (53\%), followed by diabetes in $80(32 \%)$ and a positive family history in $65(26 \%)$ patients. As against this, female patients had commonest risk factors as hypertension in $71(47 \%)$, diabetes in 71 $(47 \%)$ and smoking in $64(42 \%)$, followed by a positive family history in $47(31 \%)$, and dyslipidemia in $23(15 \%)$ patients. 
- NEPALESE HEART JOURNAL •

TABLE 1: GENDER DISTRIBUTION OF THE SAMPLE

\begin{tabular}{|l|l|}
\hline Gender & No. (\%) \\
\hline Males & $251(62 \%)$ \\
\hline Females & $153(38 \%)$ \\
\hline
\end{tabular}

TABLE 2: PREVALENCE OF RISK FACTORS IN THE TWO SEXES

\begin{tabular}{|c|c|c|c|}
\hline & Males & Females & \\
\hline 1 & Smoking & $160(64 \%)$ & $64(42 \%)$ \\
\hline 2 & Hypertension & $148(59 \%)$ & $71(47 \%)$ \\
\hline 3 & Dyslipidemia & $133(53 \%)$ & $23(15 \%)$ \\
\hline 4 & Diabetes Mellitus & $80(32 \%)$ & $71(47 \%)$ \\
\hline 5 & Positive family history & $65(26 \%)$ & $47(31 \%)$ \\
\hline
\end{tabular}

BAR DIAGRAM SHOWING PREVALENCE OF DIFFERENT RISK FACTORS.

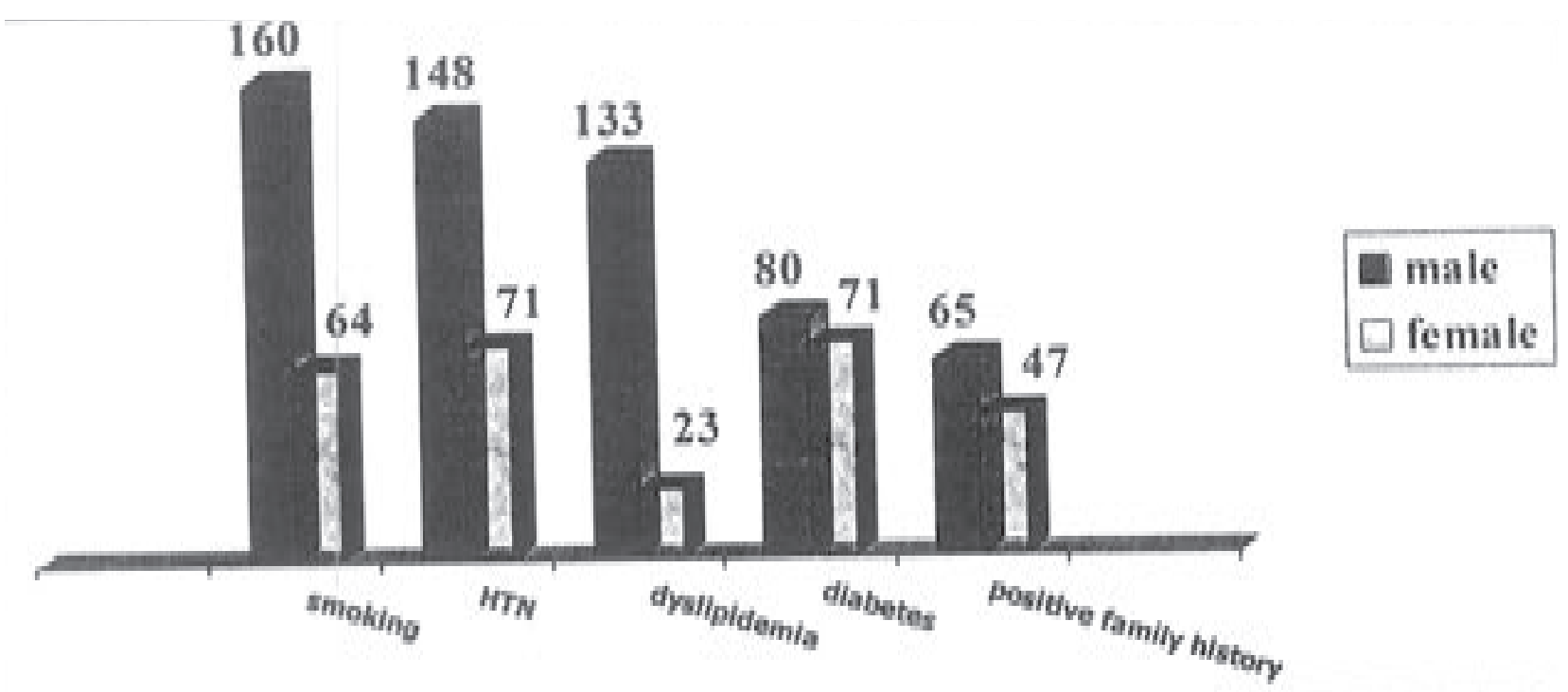




\section{TABLE 3: THE TOP 5 RISK FACTORS IN MALES \& THE FEMALES}

\begin{tabular}{|l|l|l|}
\hline \multicolumn{2}{|l|}{ Males } & Females \\
\hline 1 & Smoking 160 (64\%) & Hypertension 71 (47\%) \\
\hline 2 & Hypertension 148 (59\%) & Diabetes Mellitus 71 (47\%) \\
\hline 3 & Dyslipidemia 133 (53\%) & Smoking 64 (42\%) \\
\hline 4 & Diabetes Mellitus 80 (32\%) & Positive family history $47(31 \%)$ \\
\hline 5 & Positive family history 65 (26\%) & Dyslipidemia 23 (15\%) \\
\hline
\end{tabular}

\section{Discussion and Conclusions:}

Women suffering from an acute myocardial infarction are likely to be older and more likely to have a history of hypertension, diabetes, unstable angina, hyperlipidemia, and congestive heart failure and are less likely to be smokers than their male counterparts, ${ }^{5+15}$ In this study also, smoking was found to be the most common risk factor in male patients with acute coronary event (ACE), followed by Hypertension and Dyslipidemia, but most female patients with ACE have Hypertension as the most common coronary risk factor followed by diabetes mellitus. This may be partly due to the difference of socio-economic status of two genders in Nepal. An aggressive preventive approach is mandatory to decrease the expensive burden of coronary artery disease in this poor Himalayan country.

\section{Bibliography:}

1. Lerner, D.J., and Kannel, W, B.: Pattarns of coronary heart disease morbidity and mortality in the sexes: A 26-year follow-up of the Framingham population, Am. Heart J. 111:383, 1986.

2. Brezinka, V., and Padmos, I,: Coronary heart disease risk factors in women. Eur. Heart J. 15:1571, 1994,

3. Kannel, W, B., and McGee, D. L.: Diabetes and glucose tolerance as risk factors for cardiovascular disease: The Framingham Study, Diabetes Care 2:120, 1979. 
4. Castelli, W. P.: Epidemiology of triglycerides: A view from Framingham, Am, J. Cardiol. 70:3H, 1992,

5. Maynard, C., Litwin, PR E., Martin, J.S., and Weaver, W. D.: Gender differences in the treatment and outcome of acute myocardial infarction: Results from the myocardial infarction triage and intervention registry. Arch. Intern, Med. 152:972, 1992 ,

6. Dittrich, D., Gilpin, E., Niced, P, et al.: Acute myocardial infarction in women: Influence of gender on mortality and prognostic variables. Am, J, Cardiol. 62:1,1988.

7. Goldberg, R. J., Gorak, E. J., Yarzebski, J., et al.: A community wide perspective of sex differences and temporal trends in the incidence and survival rates after acute myocardial infarction and oul-ol-hospital deaths caused by coronary heart disease. Circulation 87:1947, 1993.

8. Puletti, M., Sunseri, L., Curione, M., et al.: Acute myocardial infarction: Sexrelated differences in prognosis, Am, Heart J. 108:63, 1984,

9. Henning, R., and Lundman, T.: The Swedish Cooperative Study, Part I: A description of the early stage. Acta Med. Scand, 586:27, 1975.

10. Weinblatt, E., Shapiro, S., and Frank, C. W.: Prognosis of women with newly diagnosed coronary heart disease: A comparison with causes of disease among men. Am. J. Public Health 63:577, 1973.

11. [Abstract] Jenkins, J. S., Flaker, G. C., Nolte, B., et al: Causes of higher in-hospital mortality in women than in men after acute myocardial infarction, Am. J. Cardiol. 73:319, 1994,

12. Wilkinson, P., Laji, K., Ranjadayalan, K., et al.: Acute myocardial infarction in women: Survival analysis in first six months, Br, Med. J. 309:566, 1994. 
13. White, H. D., Barbash, G.1., Modan, M., et al.: After correcting for worse baseline characteristics, women treated with thrombolytic therapy for acute myocardial infarction have the same mortality and morbidity as men except for a higher incidence of hemorrhagic stroke. The Investigators of the International Tissue Plasminogen Activator/Streptokinase Mortality Study. Circulation 88:2097, 1993.

14. Lincoff, A. M., Calif, R.M., Ellis, S.G., et al.: Thrombolytic therapy for women with myocardial infarction: Is there a gender gap? Thrombolysis and angioplasty in myocardial infarction study group. J. Am, Coll, Card 22:1 780, 1993,

15. Fiebach, N.H., Viscoll, C,M., and Horwitz, R. I: Differences between women and men in survival after myocardial infarction: Biology or methodology ? JAMA 263:1092, 1990.

Dr, Bharat Rawat-Consultant Cardiologist, Dr Abhinav Vaidya-Medical officer, Dr. Pravesh Basnet-Medical officer, DrJessen Gurung- Medical officer, Subhash Acharaya-Medical officer, Dr H,S, Sodhi-Consultant Cardiologist, Prof. Dr Dambar Bahadur Karki-Consultant Cardiologist,Dr. Sunil Chandra Jha-Consultant Cardiologist. 